\title{
Liver-Associated Large Granular Lymphocytes: Morphological and Functional Aspects
}

\author{
Kenji KANEDA \\ Department of Anatomy, Faculty of Medicine, Tokyo Medical and Dental University, Tokyo, Japan
}

Received September 5, 1989

\begin{abstract}
Summary. Large granular lymphocytes (LGLs) differ from other lymphocytes in their recirculation pattern and are distributed preferentially in nonlymphoid organs such as the liver and lung. The liver-associated LGLs adhere strongly to the sinusoidal endothelium and show a natural killer (NK) cytotoxicity against incoming metastatic tumor cells; this reaction occurs very rapidly because, in contrast to the immune response, it does not require complex processes in the lymphoid tissue. They have been extensively studied morphologically in terms of pit cells. LGLs have two characteristic cell organelles which participate in the NK cytolysis, $i$. e., dense granules and rod-cored vesicles. The former are lysosomes derived from multivesicular bodies and contain pore-forming proteins. The latter are the secretory vesicles exclusively seen in LGLs and are markedly increased in number when the NK function is augmented by biological response modifiers. These two structures are believed to be exocytosed in the space between LGL and the conjugated tumor cell. The microenvironment of the liver sinusoids, which includes Kupffer cells, endothelial cells and other lymphocytes, is considered to regulate the function of the liver-associated LGLs. Liver-associated LGLs, as well as Kupffer cells, are intrinsically involved in the defense system of the liver under various physiological and pathological conditions.
\end{abstract}

The liver has attracted interest by its tumor-killing function, which is mainly carried out by Kupffer cells and natural killer (NK) cells (COHEN et al., 1982, 1985; MALTER et al., 1986). Particularly, the latter cells which are identified also as "liver-associated large granular lymphocytes (LGLs)", play an important role in inhibiting metastasis formation in this organ (Wiltrout et al., 1985). Since 1976, morphological studies have been extensively performed on "pit cells" discovered and designated by WISSE et al. (1976), which, in turn, have been revealed to be LGLs or NK cells (KANEDA et al., 1983). In this review, the structure and function of the liver-associated NK cells or pit cells are dealt with from both morphological and functional aspects.

\section{NATURAL KILLER CELLS, LARGE GRANULAR LYMPHOCYTES AND PIT CELLS}

In 1975 , it was reported that nonimmunized mice spleens contained "naturally" occurring killer cells which showed spontaneous cytolysis against certain tumor cell lines in in vitro systems. These killer cells obviously differed from the cytotoxic $\mathrm{T}$ lymphocytes (CTLs), which are induced during the immune response and possess the specific cytotoxicity against tumor cells, and so were termed natural killer (NK) cells (KIESSLING et al., 1975; HERBERMAN et al., 1975). Thus NK activity described the cytolysis of certain NK-sensitive tumor cell lines in the absence of known presensitization. Recently, this has been more clearly defined as the cytotoxicity which is not restricted by a major histocompatibility complex (MHC) (LANIER et al., 1986a). This activity is closely associated with a subpopulation of lymphocytes, morphologically identified as large granular lymphocytes (LGLs) (SAKSELA et al., 1979; REYNOLDS et al., 1981), which are the large-sized cells with pale cytoplasm, slightly eccentric reniform nucleus and cytoplasmic granules on Giemsa-stained specimens (Fig. 1-Inset). The frequency of LGLs among human blood leukocytes is $2-6 \%$; at least $70 \%$ of LGLs have NK activity (TimONEN et al., 1981). Several cell populations have the morphological appearance of LGL: 1) NK cells 
(KIESSLING et al., 1975; HERBERMAN et al., 1975), which may include natural cytotoxic (NC) cells (STUTMAN et al., 1978) and $\mathrm{T}_{\mathrm{G}}$ cells (GROSSI et al., 1978); 2) a certain proportion of CTLs with or without NK activity (LANIER et al., 1986b; BIRON et al., 1986)-the majority of CTLs belong to small lymphocytes; 3) HNK- $1^{+} \mathrm{T}^{+}$LGLs (ABO et al., 1982) which are immature NK cells usually seen in the bone marrow; and 4) lymphokine-activated killer (LAK) cells (GRIMM et al., 1982) or IL-2-stimulated NK cells. Although LGLs are a heterogenous cell population and not synonymous with NK cells, the majority of LGLs are considered to be NK cells or cells closely related with NK cells.

Immunological studies on NK cells have usually been carried out using LGLs in easily sampled organs such as the spleen and peripheral blood. LGLs, however, also distribute in other organs, i.e., the lung, liver, intestine etc., where significant NK activity is detected (RICCARDI et al., 1979; LUINI et al., 1981). The liver and lung are often the sites of tumor metastasis. Since NK cells can function without the process of presensitization, they are believed to interact with and destroy tumor cells rapidly in these vital organs. WILTROUT et al. $(1984,1985)$ have shown that organassociated NK activity seen in nonlymphoid organs is very important in inhibiting metastasis formation and is carried out not by blood-borne LGLs, but by organ-associated LGLs which strongly adhere to the capillary endothelium of the organ. Although organassociated LGLs derive from blood-borne ones, they exhibit several different properties: liver- and lungassociated LGLs 1) are slightly different phenotypically from blood-borne ones (WILTROUT et al., 1984, 1985; YARBROUGH and WeISSLER, 1989); 2) they can be activated independently of the blood-borne LGLs and have a different sensitivity to in vitro treatment with anti-NK antibodies (WILTROUT et al., 1984, 1985); 3) they are subject to local regulation by coexisting resident macrophages (BORDIGNON et al., 1982; OKU. MURA et al., 1987); and 4) they possess smaller-sized cytoplasmic granules (WISSE et al., 1976).

Pit cells, which were first reported by WISSE et al. (1976) as one of the liver sinusoidal cells (Figs. 1, 2) and later morphologically characterized by multivesicular body (MVB)-derived granules and rod-cored vesicles (KANEDA et al., 1982; KANEDA and WAKE, 1983), have been revealed by us to correspond to LGLs and largely, if not all, to NK cells on the basis of their cytolytic capacity against NK sensitive tumor cells as demonstrated in vitro (KANEDA et al., 1983). This is comfirmed by their NK cytotoxicity shown in the ${ }^{51} \mathrm{Cr}$-release test (BouwENS et al., 1987) and by the expression of NK cell surface markers -all LGLs or pit cells show OX- $8^{+}, \mathrm{OX}-19^{-}$and about a half of them are asialo $\mathrm{GM}^{+}$(BouwENS and WISSE, 1987). Pit cells inside the liver tissue show positivity for asialo GM1 (ENZAN et al., 1989) (Fig. 3). They also possess a natural cytotoxic (NC) activity against solid tumor cell lines (Bouwens et al., 1988; Bo. UWENS and WISSE, 1989). The pit cells in the liver thus correspond to liver-associated LGLs and at least some of them show NK (and NC) activity.

\section{ULTRASTRUCTURAL CHARACTERISTICS OF LIVER-ASSOCIATED LGLS}

Ultrastructural studies on the liver-associated LGLs (or pit cells) have been performed in rats (WISSE et al., 1976; KANEDA and WAKE, 1983), humans (KANEDA et al., 1984; BIOULAC-SAGE et al., 1986; BouwENS et al., 1989; LAFON et al., 1989) and mice (FREUDENBERG et al., 1989). We will mainly describe here rat LGLs because the cell organelles are more abundant and the morphological characteristics are more obvious than those in other species.

Liver-associated LGLs exist in the liver sinusoid and adhere to endothelial cells or Kupffer cells. They often project cytoplasmic processes through endothelial pores and come into direct contact with hepatocytes. Their appearance in the space of Disse is not a common feature. The LGLs average ten per section of hepatic lobule, and they are distributed more frequently in the peripheral zone as well as Kupffer cells. The relative frequency of the sinusoidal cells and leukocytes remaining after perfusion was as follows; endothelial cells $21 \%$, vitamin A-storing cells $39 \%$, Kupffer cells $32 \%$, LGLs $2.5 \%$, agranular lymphocytes $3 \%$, monocytes $2.5 \%$, granulocytes $0.3 \%$ and plasma cells $0.1 \%$ (KANEDA and WAKE, 1983). Although the frequency of LGLs per section does not appear so high, their total number in the liver is sizable; in a young adult rat the liver contains $14-20 \times 10^{6}$ LGLs while $5-7 \times 10^{6}$ LGLs exist in the spleen (BouwENS et al., 1987).

LGLs are about $10 \mu \mathrm{m}$ in diameter and variable in shape. They usually show a high degree of cell polarity, i.e., most of the cell organelles reside at one aspect of the nucleus and the opposite side consists of an organelle-free hyaloplasm which often forms prominent pseudopodia (Fig. 2). The development of the cytoplasmic projections indicates that LGLs are highly motile. The nucleus is chromatin-rich and sometimes indented. There are one or two Golgi apparatuses. They consist of a few cisternae and 

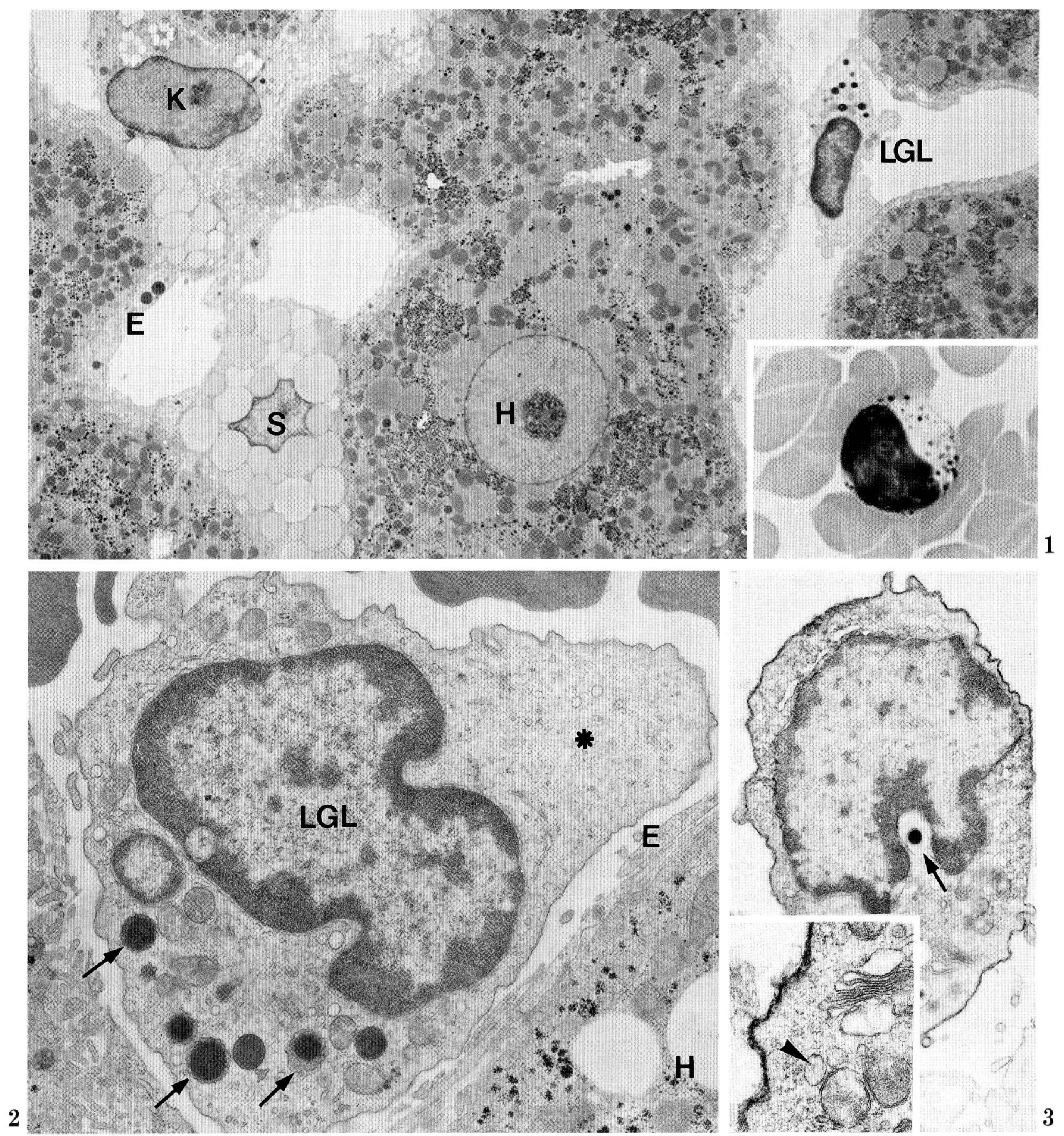

Fig. 1. Four sinusoidal cells in the rat liver: Kupffer cells $(K)$, stellate cells $(S)$, endothelial cells $(E)$ and large granular lymphocytes $(L G L)$. This animal received excess vitamin A and an injection of latex particles. $H$ hepatocyte. (Reproduced from KANEDA et al., 1982). ×2,200. Inset: A Giemsa-stained LGL in the peripheral blood. $\times 1,700$

Fig. 2. A liver-associated LGL (LGL) with dense granules (arrows) and hyaloplasm (asterisk). $\times 12,000$

Fig. 3. Immunoelectron micrograph of an asialo GM1+ LGL in the liver. Dense granules (arrow) and rod-cored vesicles (arrowhead in the inset) exist in the cytoplasm. $\times 8,600$, Inset: $\times 23,000$ 
small bristle-coated vesicles budding and pinched off from them. Near the Golgi apparatus exists a centriole, from which microtubules radiate in every direction. Several mitochondria, rough endoplasmic reticulum and free ribosomes are scattered in the cytoplasm. Glycogen particles are usually rare.

The most characteristic features of LGLs are dense granules and rod-cored vesicles. The dense granules have a diameter of $0.25-0.5 \mu \mathrm{m}$ and count, in average, eight per cell section. The dense granules of asialo GM1-positive LGLs are generally larger than those of the negative ones (BOUWENS and WISSE, 1987). In the human, three granules with an average diameter of $0.2 \mu \mathrm{m}$ are present per cell section (BIOU. LAC-SAGE et al., 1986). They correspond to azurophilic granules of the Giemsa-stained cells and are lysosomal in nature, as revealed cytochemically, i.e., acid phosphatase positive, peroxidase negative, aryl sulfatase positive (GROSSI et al., 1982; KANEDA et al., 1983; BouwENS et al., 1987; KANG et al., 1987a) and stainable with silver methenamine (WISSE et al., 1976). They sometimes contain membranous structures. The lysosomal granules of LGLs are usually spherical and larger than $0.2 \mu \mathrm{m}$ in diameter, while those of monocytes and macrophages are pleiomorphic and vary in size from very small to large; this characteristic feature of LGL granules comes from the fact that they are formed and matured through the accumulation of dense materials in multivesicular bodies (KANEDA and WAKE, 1983; GROSSI et al., 1984).

Several types of granules at different developing stages are seen in the cytoplasm: 1) granules with a smooth limiting membrane with a narrow halo between the dense material and the limiting membrane; 2) granules with an undulating limiting membrane with a wider space; 3) granules possessing small vesicles in addition to the dense material; and 4) multivesicular bodies (Fig. 4). As the granules mature with the accumulation of the dense material, their size increases and the limiting membrane becomes smoother (KANEDA and WAKE, 1983). In the human, LGLs often contain a unique structure called pararell tubular arrays (PAYNE and GLASSER, 1981) which consist of many tubular elements $18-24 \mathrm{~nm}$ in diameter. Pararell tubular arrays are observed in $5-25 \%$ of liver-associated LGLs (BouwENs et al., 1989). They are often associated with dense granules and contain acid phosphatase and aryl sulphatase (KANG et al., 1987a). Lysosomal enzymes are considered to be packaged into the granules in the area of GERL (Golgi-associated endoplasmic reticulum from which lysosomes form) (GROSSI et al., 1982).
Exyocytosis of the dense granules is not seen in a normal state, but there is a report that degranulation occurs in in vitro treatment with strontium (NEIGH . BOUR et al., 1982).

Rod-cored vesicles are small inclusions, ranging from $0.17-0.2 \mu \mathrm{m}$ in diameter, and are exclusively found in LGLs (KANEDA et al., 1982; KANEDA and WAKE, 1983). These are the secretory vesicles derived from the Golgi apparatus. They contain a straight rod-structure which is $30-50 \mathrm{~nm}$ in width and bridges across the entire diameter of the vesicle (Fig. 6). The rod is not crystalline in nature but consists of an amorphous material such as glycoprotein; both its ends continue with the internal surface of the vesicle. It may appear either as a rod or a dot, depending on the direction seen (Fig. 7). In addition, there are "empty" vesicles which are similar to the rod-cored ones but contain no visible rod-structure. Whether the "empty" vesicle actually does not contain a rod or merely appears so due to the sectioning planes which do not include rods, they are considered to be closely related to the rod-cored vesicles because their size and intracellular localization are indistinguishable from the latter. On an average, four rod-cored vesicles and eight "empty" vesicles are present per one cell section in rats (KANEDA and WAKE, 1983), while less than one rod-cored vesicle is seen in humans (BIOULAC-SAGE et al., 1986). The rod-cored vesicles arise from the end portion of the Golgi trans cisternae and often are disposed of in the vicinity of the apparatus (Fig. 5). It is rare that a rod-structure is recognized inside the Golgi cinsternae or in the vesicles being pinched off from them. The rod is believed to become visible as the vesicles mature. Exocytosis of rod-cored vesicles is strongly suggested from their close apposition with the plasma membrane, but has not yet observed.

In general, LGLs show neither endocytosis nor phagocytosis (WISSE et al., 1976). Exceptional cases reported are the phagocytosis of gram-positive bacteria (АВо et al., 1986; KANG et al., 1987b) and the endocytosis of lipopolysaccharide (KANG et al., 1988). Autophagolysosomes are, however, often seen in the normal state. They contain a dense matrix and the fragments of various cell organelles (KANEDA and WAKE, 1983). Liver-associated LGLs sometimes undergo mitosis in a normal rat (WISSE et al., 1976) and more frequently when treated with various biological response modifiers (BRMs; vide infra) (BouwENS and WISSE, 1988). This indicates that LGLs have the potential for local proliferation. 

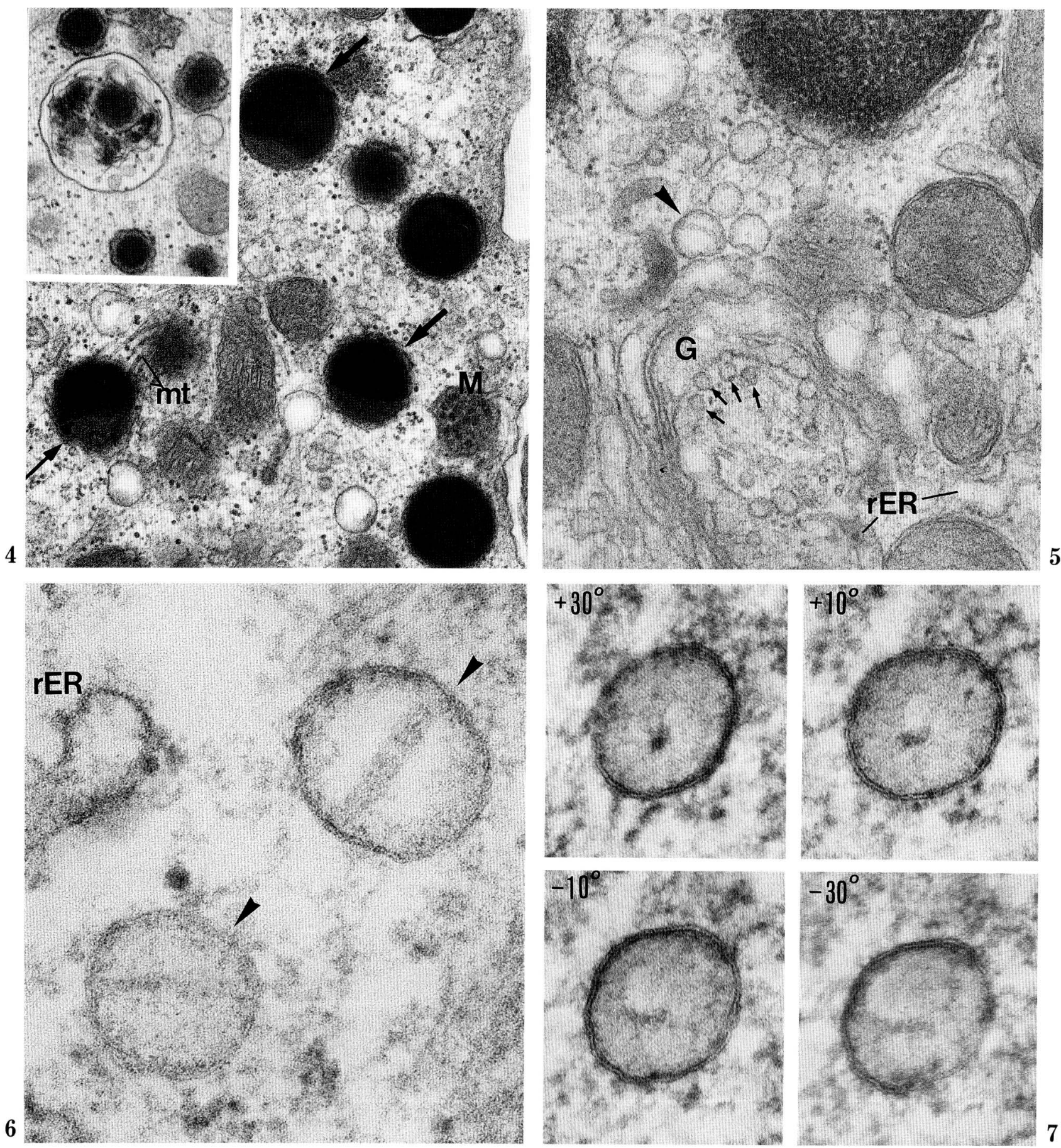

Fig. 4. Granules with only the dense matrix (arrows), those containing also small vesicles (thin arrow), multivesicular bodies $(M)$ and an autophagolysosome (inset) exist in an LGL. $\times 34,000$, Inset: $\times 28,000$

Fig. 5. A rod-cored vesicle (arrowhead) is located in the vicinity of the Golgi $(G)$ trans cisternae; transitional vesicles (arrows) from rough endoplasmic reticulum $(r E R)$ are seen at the cis portion. $\times 49,000$

Fig. 6. High magnification of rod-cored vesicles (arrowheads). $\times 180,000$

Fig. 7. Four profiles of a rod-cored vesicle seen from different angles. A rod-structure is seen as a dot at $+30^{\circ}$ whereas as a short rod at $-30^{\circ} . \times 120,000$ 


\section{DISTRIBUTION OF LGLS BY TISSUE}

LGLs generate from stem cells in the bone marrow as studies on ${ }^{89}$ strontium-treated mice (KUMAR et al., 1979) and bone marrow culture from mice (KoO et al., 1984) have indicated. Immature LGLs $\left(\mathrm{HNK}-1^{+} \mathrm{T}^{+}\right.$ LGL) in the bone marrow contain sparse azurophilic granules, and with the differentiation and maturation of the cell the granules become abundant, as seen in the blood-borne LGLs (ABO et al., 1983). Several LGLs in the bone marrow already bear ultrastructural characteristics such as dense granules and rod-cored vesicles (KANEDA and WAKE, 1985). For the differentiation and maturation of LGLs, a microenvironment of the intact bone marrow is essential (KUMAR et al., 1979).

After maturation, LGLs are released into the peripheral blood. During circulation, a certain proportion of them lodge in various organs and tissues as other lymphocytes do. The organs where the lymphocytes localize are divided into three groups: 1) lymphoid organs (lymph nodes, thymus and spleen); and 2) nonlymphoid organs, i) intravascular spaces (liver and lung) and ii) intraepithelial regions (intestine, epididymis and trachea) (KANEDA and WAKE, 1985). In the liver and lung, LGLs usually exist inside the capillaries adhering to the endothelium; their migration to the extravascular space is not so frequent. In the spleen, LGLs are rich in the red pulp but rare in the white pulp. In the intestine, LGLs exist between epithelial cells and are found mostly near the basement membrane. Intestinal LGLs contain only a few very large granules (VANDERKERKEN et al., 1989). In the rat colon, $91 \%$ of the intraepithelial lymphocytes and $21 \%$ of the lymphocytes existing in the lamina propria are LGLs possessing NK activity (NAUSS et al., 1984), while human intestine contains few NK cells (GREENWOOD et al., 1983). In the lymph nodes and thymus very small numbers of LGLs are present. In nude rats, however, many LGLs localize in the lymph nodes which become hyperplastic due to the persistent low-grade infection (WARD et al., 1983; ROLSTAD et al., 1986).

Thus, in general, LGLs are distributed in the nonlymphoid organs rather than the lymphoid organs, where agranular lymphocytes are mainly located (KANEDA and WAKE, 1985; RolstAD et al., 1986). This variance can be explained by the different recirculation pattern between the LGLs and agranular $\mathrm{T}$ and B cells (ROLSTAD et al., 1986). LGLs do not recirculate from blood to lymph, so they fail to enter most of the peripheral lymphoid tissues. Therefore, in the spleen,
LGLs move to the red pulp from the marginal zone, unlike $\mathrm{T}$ or $\mathrm{B}$ cells which directly enter the white pulp from the marginal zone (ROLSTAD et al., 1986). The preferential adherence of LGLs to capillary endothelial cells is another explanation for the enrichment of LGLs in the liver and lung. The comparison between the proportion of various leukocytes adhering to the liver sinusoidal wall with that in the peripheral blood indicates that LGLs are more adhesive to the sinusoidal wall than are agranular lymphocytes (Table 1). The preferential adherence of LGLs has also been shown in an in vitro experiment using monolayer cultured microvascular endothelial cells, and the binding is considered to be done via a specific receptor (leukocyte functioning antigen-1, LFA-1)-ligand interaction (BENDER et al., 1987).

After the blood-borne LGLs come to localize in the liver, they are considered to differentiate into phenotypically distinct LGLs which express no asialo GM1 and have smaller-sized granules and a lower cellular density than the blood-borne ones. About $50 \%$ of liver LGLs are calculated to be this "specific" type (VAN. DERKERKEN et al., 1989).

Table 1. Percentage of leucocytes in the peripheral blood and perfused liver of rats

\begin{tabular}{lcc}
\hline & $\begin{array}{c}\text { Peripheral } \\
\text { blood*(\%) }\end{array}$ & $\begin{array}{c}\text { Perfused } \\
\text { liver**(\%) }^{*}(\%)\end{array}$ \\
\hline $\begin{array}{l}\text { Large granular } \\
\text { lymphocytes (LGL) }\end{array}$ & 0.8 & 28.1 \\
Agranular lymphocytes & 75.3 & 38.3 \\
Monocytes & 1.9 & 28.1 \\
Granulocytes & 21.9 & 5.5 \\
\hline
\end{tabular}

*Value from one rat

**Average value of three liver lobules from two rats, counted on toluidine blue-stained semithin sections

\section{BRMS AND “ACTIVATED” LIVER-ASSOCIATED LGLs}

Biological response modifiers (BRMs) signify agents which increase the host's antitumor responses through the augmentation of various effector cells (OLDHAM, 1983). Several BRMs such as OK-432 (streptococcal preparation), Propionibacterium acnes and malic anhydride divinyl ether-2 (MVE-2) can induce the augmentation of NK activity. When they are administered, liver-associated NK activity is augmented more significantly than that of the spleen (WILTROUT et al., 1984). 

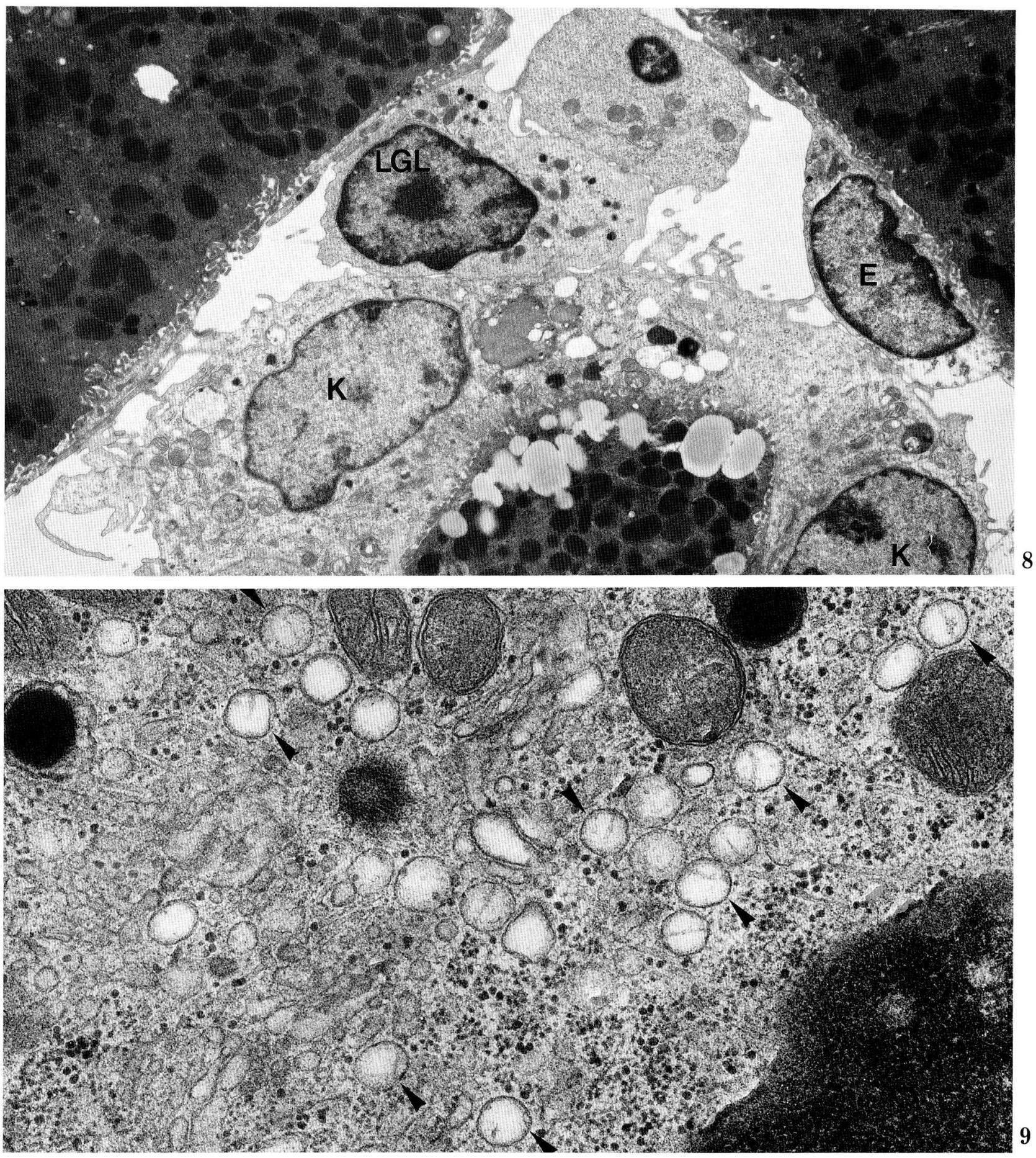

Figs. 8 and 9. LGLs in a Nocardia glucose mycolate-treated liver. In Fig. 8, an LGL comes into close wide-surfaced apposition with a Kupffer cell $(K)$. $E$ endothelial cell. (Reproduced from KAnEDA et al., 1986). $\times 4,700$. Fig. 9 shows an increased number of rod-cored vesicles (arrowheads) in an LGL. $\times 41,000$ 
Two mechanisms are responsible for the augmentation of the liver-associated NK activity by BRMs. One is the increase in the number of LGLs, and the other is the induction of "activated" LGLs by BRMs. Histologically, in a BRM-treated liver, infiltration of mononuclear cells is observed (WILTROUT et al., 1986). The number of LGLs shows a 10 to 50 -fold increase in mice (WILtrout et al., 1984) and a 4 to 6 -fold increase in rats (BOUwENS and WISSE, 1988). The increased numbers of LGLs are considered to newly derive from the bone marrow in the case of MVE-2 (WILTROUT et al., 1989) and to result mainly from the local proliferation of preexisting LGLs in the case of zymosan (BOUWENS and WISSE, 1988). Intercellular adhesion molecule (ICAM)-1, which is a ligand for LFA-1 and is induced by several cytokines, may also participate in the accumulation of LGLs by providing the localizing sites on the endothelial cells.

$\mathrm{BRMs}$ are also considered to induce activation of liver-associated LGLs. In an OK-432- or a mycolic acid-containing glycolipid-treated liver, several LGLs possess a well developed Golgi apparatus, many glycogen particles and, most characteristically, an increased number of rod-cored vesicles (DAN et al., 1985, 1986; KANEDA et al., 1986) (Fig. 9). The size of granules also increases at $72 \mathrm{~h}$ after the administration of OK-432 (TANAKA et al., 1989). These figures denote the enhanced secretory function of the cells are considered to be the morphological expression of "activated" liver-associated LGLs.

In the augmentation of liver-associated NK activity by BRMs, Kupffer cells also play an important role. They incorporate OK- 432 or glycolipids into the phagolysosomes and become activated. They then increase in number and often come into close apposition with LGLs in the sinusoids (DAN et al., 1985, 1986; KANEDA et al., 1986) (Fig. 8). One report states that resident macrophages activate LGLs through direct cellular contact by inducing interleukin (IL)-2 receptors on the surface of LGLs (MINATO et al., 1985). On the other hand, Kupffer cells inhibit NK activity by producing prostaglandins (OKUMURA et al., 1987). The function of the liver-associated LGLs are considered to be regulated locally through contact with the cellular components existing in the liver such as Kupffer cells, endothelial cells and other lymphocytes, as well as through various cytokines produced by them.

The in vitro culture of NK cells with IL-2 induces the occurrence of broadly cytotoxic antitumor killer cells, termed lymphokine-activated killer (LAK) cells (GrImM et al., 1982; VUJANOVIC et al., 1988). Until today, no ultrastructural comparison between NK cells and LAK cells has ever been done. One report available in this context concerns feline LAK cells which possess many multivesicular bodies (MVB) (although the authors did not use the term MVB) (TOMPKINS et al., 1989).

\section{FUNCTIONAL ROLE OF LIVER-ASSOCIATED LGLs}

NK cells are known to aid in the resistence to tumors and virus infection, in immunoregulation and hematopoietic homeostasis (for review, TRINCHIERI and Perussia, 1984). Among these, NK cell-mediated cytotoxicity against tumor cells is the phenomenon which has been most extensively studied (for review, HENKART, 1985).

NK cytolysis is similar to that of CTLs in the lytic process and the cytolytic mediators (HENKART, 1985). Its process is divided into three steps (HISERODT et al., 1982): i) binding to target cells; ii) programming for lysis; and iii) killer cell-independent cytolysis. Morphological features of the lytic process seen in the in vitro effector cell-target cell conjugation are as follows. When an NK cell adheres to a tumor cell, actin and vinculin are polarized in the contact area (CARPÉN et al., 1983) where they protrude and withdraw cytoplasmic projections against the target cell, as revealed by the microcinematography of living CTLs (RYSER et al., 1982). Reorientation of the Golgi apparatus and the microtubule-organizing center toward the target cell then occurs rapidly, followed by secretion of the cytotoxic components from the NK cell directed to the bound tumor cell (CARPEN et al., 1982; KUPFER et al., 1983) (Figs. 10, 11). Several mechanisms are believed responsible for the NK cytolysis: i) Perforins in the dense granules makes ring structures of $\sim 15 \mathrm{~nm}$ internal diameter on the plasma membrane of the target cell (PODACK and DENNERT, 1983). The figure of an exocytosed dense matrix is sometimes seen between the LGL and the tumor cell (SchmidT et al., 1988). ii) Rod-cored vesicles, with a content yet unknown, have been demonstrated to be transported toward the bound target cell along microtubules (KANEDA et al., unpublished). iii) NK cytotoxic factor (WRIGHT and BONAVIDA, 1982). Its intracellular localization is unknown. iv) Cytoplasmic projections may participate in the cell lysis, as reported in CTLs (SANDERSON and GLAUERT, 1979). NK cells also extend the projections into the bound tumor cells (Fig. 10).

There is morphological evidence that liver-associated LGLs or NK cells actually function also in 


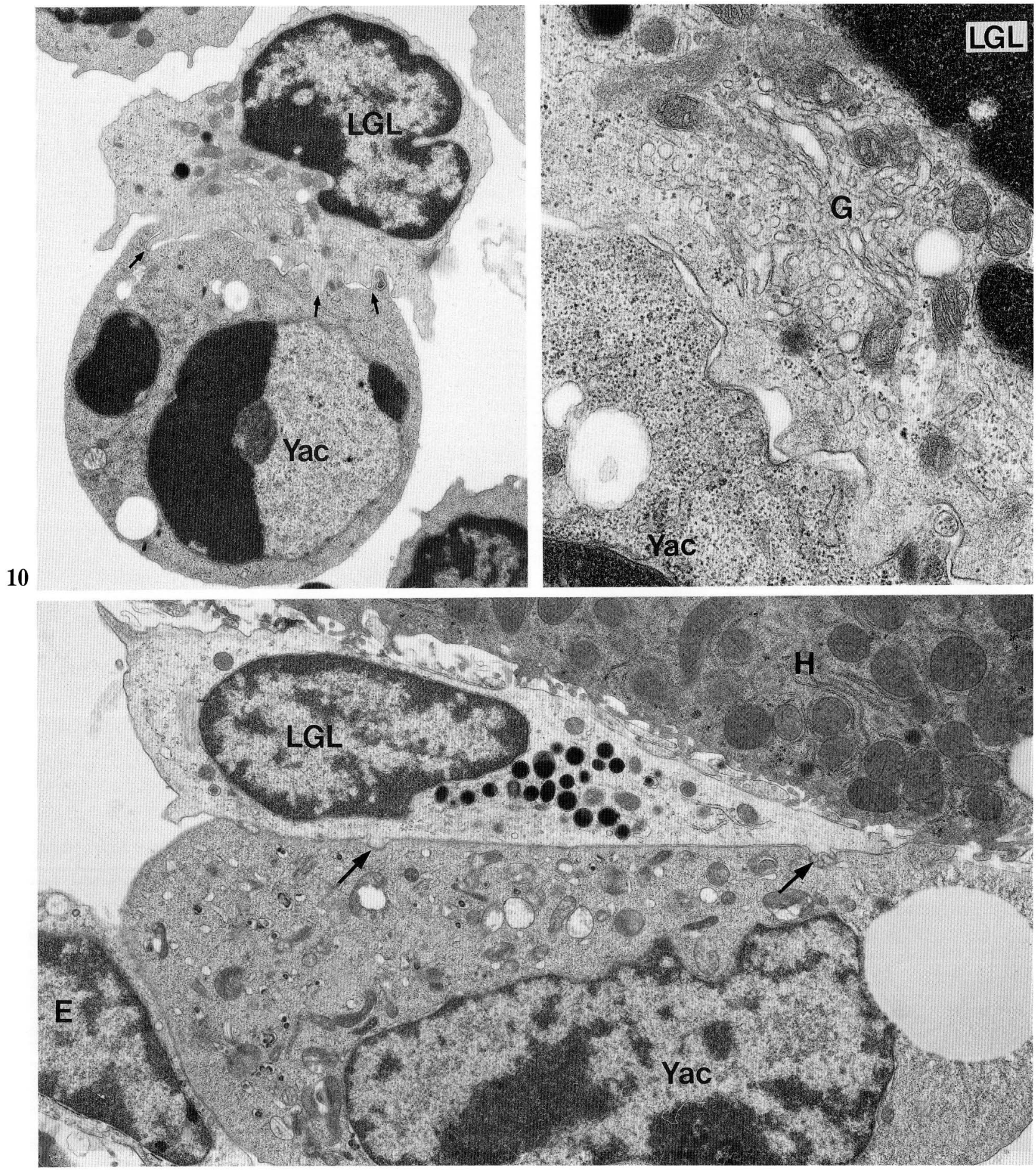

Figs. 10 and 11. The conjugate of a spleen LGL and a Yac-1 cell ( Yac) after $3 \mathrm{~h}$ incubation. A well-developed Golgi apparatus $(G)$ and many small vesicles (Fig. 11) face the degenerating target cell. Cytoplasmic projections are protruded into the target (arrows). $\times 27,000$

Fig. 12. The conjugate of an LGL and an injected Yac-1 cell ( $Y a c)$ in the liver. Small processes are extended into the target cell (arrows). $E$ endothelial cell, $H$ hepatocyte. $\times 7,800$ 


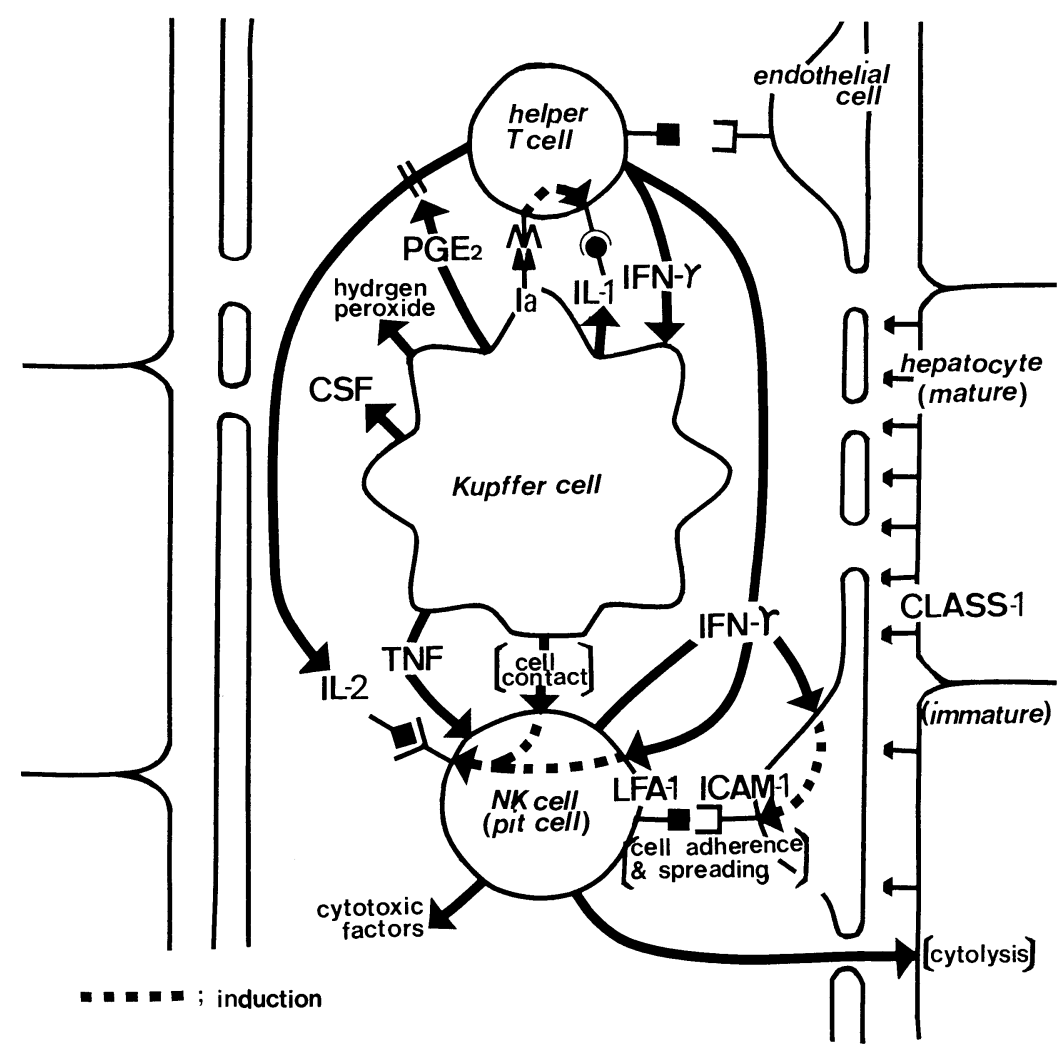

Fig. 13. A diagram of a possible cellular interaction which locally regulates the function of LGLs in the liver. CSF colony-stimulating factors, CLASS-1 class-1 antigens, Ia Ia antigens, ICAM-1 intercellularadhesion molecule-1, IFN- $\gamma$ interferon- $\gamma, I L-1,2$ interleukin-1, 2 , $L F A-1$ lymphocyte function-associated antigen-1, $P G E_{2}$ prostaglandin $\mathrm{E}_{2}$, $T N F$ tumor necrosis factors. vivo. When NK sensitive tumor cells are experimentally injected into a portal vein, liver-associated LGLs bind to and lyse them inside the sinusoids in a similar way as seen in in vitro conjugation (KANEDA et al., 1989) (Fig. 12). In human hepatocyte carcinoma, NK cells (Leu- $7^{+}$cells) are in close association with tumor cells (SI and WHITESIDE, 1983). In autoimmune hepatitis, LGLs sometimes migrate into the space of Disse and contact hepatocytes (KANEDA et al., 1984).

There is, furthermore, evidence supporting the view that the liver-associated NK cells exert a regulatory function in the growth of the hepatocytes. Immature one-nucleus hepatocytes, frequently seen in a regenerating liver, are more susceptible to NK cytolysis than mature binuclei hepatocytes (ITOH et al., 1988).

In summary, liver-associated LGLs play an important role in the defense system of the liver. Their function is regulated locally by other cellular components existing inside the liver (Fig. 13) and is closely related with morphologically unique cell organelles. In the study of liver-associated LGLs, not only the immunological aspect but also the histological one is considered to be highly pertinent.

\section{REFERENCES}

ABo, T., M. D. Cooper and C. M. BaLCh: Characterization of HNK-1+ (Leu-7) human lymphocytes. I. Two distinct phenotypes of human NK cells with different cytotoxic capability. J. Immunol. 129: 1752-1757 (1982).

Abo, T., C. A. Miller, G. Larry Gartland and C. M. BALCH: Differential stages of human natural killer cells in lymphoid tissues from fetal to adult life. J. Exp. Med. 157: 273-284 (1983).

Abo, T., S. Sugawara, A. Amenomori, H. Itoh, H. RIKIISHI, I. Moro and K. KumagaI: Selective phagocytosis of gram-positive bacteria and interleukin 1 like factor production by a subpopulation of large granular lymphocytes. J. Immunol. 136: 3189-3197 (1986).

Bender, J. R., R. Pardi, M. A. Karasek and E. G. ENGLEMAN: Pheotypic and functional characterization of lymphocytes that bind human microvascular endothelial cells in vitro. Evidence for preferential binding of natural killer cells. J. Clin. Invest. 79: 1679-1688 (1987).

Bioulac-Sage, P., P. Latry, J. Dubroca, A. Quinton and C. Balabaud: Pit cells in human liver. In: (ed. by) 
S. KIRN, D. L. KNOOK and E. Wisse: Cells of the hepatic sinusoid, Vol. 1. Kupffer Cell Foundation, Rijswijk, 1986 (p. 415-420).

Biron, C. A., R. J. NATUK and R. M. WeLSh: Generation of large granular $\mathrm{T}$ lymphocytes in vivo during viral infection. J. Immunol. 136: 2280-2286 (1986).

Bordignon, C., F. Villa, P. Allavena, M. Introna, A. Biondi, R. Avallone and A. Mantovani: Inhibition of natural killer activity by human bronchoalveolar macrophages. J. Immunol. 129: 587-591 (1982).

Bouwens, L. and E. Wisse: Immuno-electron microscopic characterization of large granular lymphocytes (natural killer cells) from rat liver. Eur. J. Immunol. 17: 1423-1428 (1987)

- - Tissue localization and kinetics of pit cells or large granular lymphocytes in the liver of rats treated with biological response modifiers. Hepatology 8: 46-52 (1988)

- : Hepatic pit cells have natural cytotoxic (NC) activity against solid tumor-derivated cells. In: (ed. by) E. WISSE, D. L. KNOOK and K. DECKer: Cells of the hepatic sinusoid, Vol. 2. Kupffer Cell Foundation, Rijswijk, 1989 (p. 215-220).

Bouwens, L., L. Remels, M. Baekeland, H. Van Bos SUYT and E. WISSE: Large granular lymphocytes or "pit cells" from rat liver: isolation, ultrastructural characterization and natural killer activity. Eur. J. Immunol. 17: 37-42 (1987).

Bouwens, L., R. Jacobs, L. Remels and E. Wisse: Natural cytotoxicity of rat hepatic natural killer cells and macrophages against a syngeneic colon adenocarcinoma. Cancer Immunol. Immunother. 27: 137-141 (1988).

Bouwens, L., A. Brouwer and E. Wisse: Ultrastructure of human pit cells. In: (ed. by) E. WISSE, D. L. KNOOK and K. DECKER: Cells of the hepatic sinusoid, Vol. 2. Kupffer Cell Foundation, Rijswijk, 1989 (p. 471-476).

Carpén, O., I. VirTanen and E. Saksela : Ultrastructure of human natural killer cells: Nature of the cytolytic contacts in relation to cellular secretion. J. Immunol. 128: 2691-2697 (1982).

Carpén, O., I. Virtanen, V.-P. Lehto and E. Saksela: Polarization of NK cell cytoskeleton upon conjugation with sensitive target cells. J. Immunol. 131: 2695-2698 (1983).

Cohen, S. A., D. Salazar and J. P. Nolan: Natural cytotoxicity of isolated rat liver cells. J. Immunol. 129: 495-501 (1982).

Cohen, S. A., D. Salazar, W. Von Muenchhausen, M. WERNER-WASIK and J. P. NolAN : Natural antitumor defense system of the murine liver. J. Leuk. Biol. 37: 559-569 (1985).

DAN, C., K. KANEDA and K. W AKE: A striking increase in rod-cored vesicles in pit cells (natural killer cells) and augmentation of the liver-associated natural killer activity by a streptococcal preparation (OK-432). Biomed. Res. 6: 347-351 (1985).

: Pit cells and liver-associ- ated natural killer activity following administration of OK-432. In: (ed. by) A. KIRN, D. L. DECKER and E. WISSE: Cells of the hepatic sinusoid, Vol. 1. Kupffer Cell Foundation, Rijswijk, 1986 (p. 427-432).

Enzan, H., S. Iwamura, S. Watanabe, T. Saibara, S. OHNishi, Y. Yamamoto, H. Yamamoto and H. HARA: Immunoelectron microscopic identification of pit cells in the rat and mouse livers. In: (ed. by) E. WISSE, D. L. KNOOK and K. DECKER: Cells of the hepatic sinusoid, Vol. 2. Kuffer Cell Foundation, Rijswijk, 1989 (p. 479480 ).

Fredenberg, N., J. Schalk, C. Galanos, T. Katschinski, O. Datz, U. Pein and M. A. Freudenberg: Identification and percentage frequency of isolated non-parenchymal liver cells (NPLC) in the mouse. Virchows Archiv. B. Cell Pathol. 57: 109-115 (1989).

Greenwood, J. H., L. L. Austin and W. O. Dobbins, III : In vitro characterization of human intestinal intraepithelial lymphocytes. Gastroenterology 85: 1023-1035 (1983).

Grimm, E. A., A. Mazumder, H. Z. Zhang and S. A. ROSENBERG: Lymphokine-activated killer cell phenomenon. Lysis of natural killer-resistant fresh solid tumor cells by interleukin-2-activated autologous human peripheral blood lymphocytes. J. Exp. Med. 155: 18231841 (1982).

Grossi, C. E., S. R. Webb, A. ZicCA, P. M. LydyaRd, L. Moretta, M. C. Mingari and M. D. Cooper: Morphological and histochemical analyses of two human T-cell subpopulations bearing receptors for IgM or IgG. J. Exp. Med. 147: 1405-1417 (1978).

Grossi, C. E., A. Cadoni, A. Zicca, A. Leprini and M. FERRARINI: Large granular lymphocytes in human peripheral blood: Ultrastructural and cytochemical characterization of the granules. Blood 59: 277-283 (1982).

Grossi, C. E., A. Zicca, A. Leprini, A. Cadoni, F. Pandolfi, V. L. Burgio, S. Romagnani, C. Guglielmi and M. Ferrarini: Granule formation in large granular lymphocytes (LGL). Ultrastructural and cytochemical studies on cells from patients with abnormally expanded LGL populations. J. Submicrosc. Cytol. 16: 759-771 (1984).

HenkaRT, P. A.: Mechanism of lymphocyte-mediated cytotoxicity. Ann. Rev. Immunol. 3: 31-58 (1985).

Herberman, R. B., M. E. Nunn and D. H. Lavrin: Natural cytotoxic reactivity of mouse lymphoid cells against syngeneic and allogeneic tumors. I. Distribution of reactivity and specificity. Int. J. Cancer 16: 216-229 (1975).

Hiserodt, J. C., L. J. Britvan and S. R. Targan: Characterization of the cytolytic reaction mechanism of the human natural killer (NK) lymphocyte: resolution into binding, programming, and killer cell-independent steps. J. Immunol. 129: 1782-1787 (1982).

Itoh, H., T. Abo, S. Sugawara, A. Kanno and K. KUMAGAI: Age-related variation in the proportion and activity of murine liver natural killer cells and their cytotoxicity against regenerating hepatocytes. J. Immunol. 141: 315-323 (1988). 
KANEDA, K. and K. WAKE: Distribution and morphological characteristics of the pit cell of the rat. Cell Tiss. Res. 233: 485-505 (1983).

- : Pit cells in extrahepatic organs of the rat. Anat. Rec. 211: 192-197 (1985).

Kaneda, K., K. WaKe and H. Senoo: The 'rod-cored vesicle': A new type of vesicle in the pit cells. In: (ed. by) D. L. KNOOK and E. WISSE: Sinusoidal liver cells. Elsevier, Amsterdam, 1982 (p. 77-84).

KANEDA, K., C. DAN and K. WAKE: Pit cells as natural killer cells. Biomed. Res. 4: 567-576 (1983).

Kaneda, K., N. Kurioka, S. SeKi, K. Wake and S. Yaмaмото: Pit cell-hepatocyte contact in autoimmune hepatitis. Hepatology 4: 955-958 (1984).

Kaneda, K., I. Yano, Y. SUmi, S. Kotera, K. Kato, C. Dan, K. Мотомatsu and K. WAKE: Kupffer cell-pit cell contact and granuloma formation in the liver by mycolic acid-containing glycolipids from Nocardia rubura. In: (ed. by) A. KIRN, D. L. KNOOK and E. WISSE: Cells of the hepatic sinusoid, Vol. 1. Kupffer Cell Foundation, Rijswijk, 1986 (p. 421-426).

Kaneda, K., Y. Natsuhara, S. OKa, K. Uehara, I. YANO and K. WAKE: In vivo defensive role of pit cells in the liver. In: (ed. by) E. Wisse, D. L. KNook and K. DECKER: Cells of the hepatic sinusoid, Vol. 2. Kupffer Cell Foundation, Rijswijk, 1989 (p. 221-223).

Kang, Y-H., M. Carl, P. M. Grimley, S. Serrate and L. YAFFE: Immunoultrastructural studies of human NK cells: I. Ultracytochemistry and comparison with T cell subsets. Anat. Rec. 217: 274-289 (1987a).

Kang, Y-H., M. Carl, L. P. Watson and L. Yaffe: Immunoultrastructural studies of human NK cells: II. Effector-target cell binding and phagocytosis. Anat. Rec. 217: 290-304 (1987b).

Kang, Y-H., M. Carl, R. K. Maheshwari, L. P. Wat SON, L. YAFFE and P. M. GRIMLEY: Incorporation of bacterial lipopolysaccharide by human Leu- $11 \mathrm{a}^{+}$natural killer cells. Ultrastructural and functional correlations. Lab. Invest. 58: 196-209 (1988).

KIEsSLing, R., E. KLeIN and H. WigzeLL: Natural killer cells in the mouse. I. Cytotoxic cells with specificity for mouse Moloney leukemia cells. Specificity and distribution according to genotye. Eur. J. Immunol. 5: 112-117 (1975).

Koo, G., J. R. PepPard and W. H. MARK: Natural killer cells generated from bone marrow culture. J. Immunol. 132: 2300-2304 (1984).

Kumar, V., J. Ben-Ezra, M. Bennett and G. Sonnen . FELD: Natural killer cells in mice treated with ${ }^{89}$ strontium: normal target-binding cell numbers but inability to kill even after interferon administration. J. Immunol. 123: 1832-1838 (1979).

Kupfer, A., G. Dennert and S. J. Singer: Polarization of the Golgi apparatus and the microtubule-organizing center within cloned natural killer cells bound to their targets. Proc. Nat. Acad. Sci. 80: 7224-7228 (1983).

Lafon, M. E., A. Boulard, P. Bioulac-Sage, L. Dubuisson, J. SARIC and C. Balabaud: Isolation of pit cells from human liver: preliminary results. In: (ed. by) E. WISSE, D. L. KNOOK and K. DECKER: Cells of the hepatic sinusoid, Vol. 2. Kupffer Cell Foundation, Rijswijk, 1989 (p. 488-489).

Lanier, L. L., J. H. Phillips, J. Hackett, Jr., M. Tutt and V. KUMAR: Natural killer cells: Definition of a cell type rather than a function. J. Immunol. 137: 2735-2739 (1986a).

LaNier, L. L., A. M. LE, C. I. Civin, M. R. LoKen and J. H. Phillips: The relationship of CD16 (Leu-11) and Leu-19 (NKH-1) antigen expression on human peripheral blood NK cells and cytotoxic T lymphocytes. J. Immunol. 136: 4480-4486 (1986b).

Luini, W., D. Boraschi, S. Alberti, A. Aleotti and A. TAgLiabue: Morphological characterization of a cell population responsible for natural killer activity. Immunology 43: 663-668 (1981).

Malter, M., E. Friedrich and R. Süss: Liver as a tumor cell killing organ: Kupffer cells and natural killers. Cancer Res. 46: 3055-3060 (1986).

Minato, N., T. Amagi, J. Yodoi, T. Diamanstein and S. KAN0: Regulation of the growth and functions of cloned murine large granular lymphocyte lines by resident macrophages. J. Exp. Med. 162: 1161-1181 (1985).

Nauss, K. M., T. M. Pavlina, V. Kumar and P. M. NEWBERNE: Functional characteristics of lymphocytes isolated from the rat large intestine. Response to T-cell mitogens and natural killer cell activity. Gastroenterology 86: 468-475 (1984).

Neighbour, P. A., H. S. Huberman and Y. Kress: Human large granular lymphocytes and natural killing: ultrastructural studies of strontium-induced degranulation. Eur. J. Immunol. 12: 588-595 (1982).

OKumura, Y., H. Ishibashi, M. Shirahama, S. KuroKaWA, J. KUdo, H. OKUBo and Y. NiHo: Kupffer cells modulate natural killer cell activity in vitro by producing prostaglandins. Cell. Immunol. 107: 89-98 (1987).

OLDHAM, R. K.: Biological response modifiers. J. Nat. Cancer Inst. 70: 789-796 (1983).

Payne, C. M. and L. GLASSER: Evaluation of surface markers on normal human lymphocytes containing parallel tubular arrays: a quantitative ultrastructural study. Blood 57: 567-573 (1981).

Podack, E. R. and G. Dennert: Assembly of two types of tubule with putative cytolytic function by cloned natural killer cells. Nature (Lond.) 302: 442-445 (1983).

Reynolds, C. W., T. Timonen and R. B. Herberman: Natural killer (NK) cell activity in the rat. I. Isolation and characterization of the effector cells. J. Immunol. 127: 282-287 (1981).

Riccardi, C., P. Puccetti, A. Santoni and R. B. Her BERMAN : Rapid in vivo assay of mouse natural killer cell activity. J. Nat. Cancer Inst. 63: 1041-1045 (1979).

Rolstad, B., R. B. Herberman and C. W. Reynolds: Natural killer cell activity in the rat. V. The circulation patterns and tissue localization of peripheral blood large granular lymphocytes (LGL). J. Immunol. 136: 2800-2808 (1986). 
Ryser, J-E., E. Rugger-Brändle, C. Chaponnier and G. Gabbiani: The area of attachment of cytotoxic $T$ lymphocytes to their target cells shows high motility and polarization of actin but not myosin. J. Immunol. 128: 1159-1162 (1982).

Saksela, E., T. Timonen, A. RANKI and P. HäYRY: Morphological and functional characterization of isolated effector cells responsible for human natural killer activity to fetal fibroblasts and to cultured cell line targets. Immunol. Rev. 44: 71-123 (1979).

Sanderson, C. J. and A. M. Glauert: The mechanism of T-cell mediated cytotoxicity. VI. T cell projections and their role in target cell killing. Immunology 36 : 119-129 (1979).

Schmidt, R. E., J. P. Caulfield, J. Michon, A. Hein, M. M. Kamada, R. P. MacDermott, R. L. Stevens and J. RITZ: T11/CD2 activation of cloned human natural killer cells results in increased conjugate formation and exocytosis of cytolytic granules. J. Immunol. 140: 991-1002 (1988).

Si, L. and T. L. Whiteside: Tissue distribution of human NK cells studied with anti-Leu- 7 monoclonal antibody. J. Immunol. 130: 2149-2155 (1983).

Stutman, 0., C. J. Paige and E. F. Figarella: Natural cytotoxic cells against solid tumors in mice. I. Strain and age distribution and target cell susceptibility. J. Immunol. 121: 1819-1826 (1978).

Tanaka, M., H. Ogata, K. Yoshimoto, K. NogUchi, M. Sata, M. Abe and K. Tanikawa: Harvest of liver sinusoidal large granular lymphocytes (pit cells) and augmentation of natural killer activity by the administration of OK-432. In: (ed. by) E. WISSE, D. L. KNOOK and K. DECKER: Cells of the hepatic sinusoid, Vol. 2. Kupffer Cell Foundation, Rijswijk, 1989 (p. 451-455).

Timonen, T., J. R. Ortaldo and R. B. Herberman: Characteristics of human large granular lymphocytes and relationship to natural killer and $\mathrm{K}$ cells. J. Exp. Med. 153: 569-582 (1981).

Tompkins, M. B., V. F. Pang, P. A. Michaely, R. I. Feinmehl, E. J. Basgall, T. V. Baszler, J. F. ZACHARY and W. A. A. Tompkins: Feline cytotoxic large granular lymphocytes induced by recombinant human IL-2. J. Immunol. 143: 749-754 (1989).

Trinchieri, G. and B. Perussia: Human natural killer cells: Biologic and pathologic aspects. Lab. Invest. 50: 489-513 (1984).

VANDERKERKen, K., L. Bouwens and E. Wisse: Heterogeneity and differentiation of pit cells, or large granular lymphocytes of the rat. In: (ed. by) E. WISSE, D. L. KNOOK and K. DECKER: Cells of the hepatic sinusoid, Vol. 2. Kupffer Cell Foundation, Rijswijk, 1989 (p. 456461).

Vujanovic, N. L., R. B. Herberman, M. W. Olszowy, D. V. Cramer, R. R. Salup, C. W. Reynolds and J. C. HISERODT: Lymphokine-activated killer cells in rats: Analysis of progenitor and effector cell phenotype and relationship to natural killer cells. Cancer Res. 48: 884890 (1988).
W ard, J. M., F. Argilan and C. W. Reynolds: Immunoperoxidase localization of large granular lymphocytes in normal tissues and lesions of athymic nude rats. J. Immunol. 131: 132-139 (1983).

Wiltrout, R. H., B. J. Mathieson, J. E. Talmadge, C. W. ReYnolds, S-R. Zhang, R. B. Herberman and J. R. ORTALDO: Augmentation of organ-associated natural killer activity by biological response modifiers. Isolation and characterization of large granular lymphocytes from the liver. J. Exp. Med. 160: 1431-1449 (1984).

Wiltrout, R. H., R. B. Herberman, S-R. Zhang, M. A. Chirigos, J. R. Ortaldo, K. M. Green, Jr. and J. E. TAlmadGe: Role of organ-associated NK cells in decreased formation of experimental metastasis in lung and liver. J. Immunol. 134: 4267-4275 (1985).

Wiltrout, R. H., A. C. Denn, III and C. W. Reynolds: Augmentation of organ-associated NK activity by BRMs: Association of NK activity with mononuclear cell infiltration. Pathol. Immunopathol. Res. 5: 219-233 (1986).

Wiltrout, R. H., M. E. Gruys and P. E. Urias: Inhibition of organ-associated NK activity by ${ }^{89} \mathrm{Sr}$. In: (ed. by) E. W. ADES and C. LOPEZ: Natural killer cells and host defense. Karger, Basel, 1989 (p. 55-58).

Wisse, E., J. M. VAN'T NoORdende, J. VAN DER Meulen and W. Th. Daems: The pit cell: Description of a new type of cell occuring in rat liver sinusoids and peripheral blood. Cell Tiss. Res. 173: 423-435 (1976).

Wright, S. C. and B. Bonavida: Studies on the mechanism of natural killer (NK) cell-mediated cytotoxicity (CMC). I. Release of cytotoxic factors specific for NK-sensitive target cells (NKCF) during co-culture of NK effector cells with NK target cells. J. Immunol. 129: 433-439 (1982).

YARBRough, W. C., Jr. and J. C. Weissler: Human pulmonary NK cells: Functional and phenotypic characteristics of IL-2 responsive cells. In: (ed. by) E. W. ADES and C. LOPEZ: Natural killer cells and host defense. Karger, Basel, 1989 (p. 246-257).

\author{
Dr. Kenji KANEDA \\ Department of Anatomy \\ Faculty of Medicine \\ Tokyo Medical and Dental University \\ Yushima-1-5-45, Bunkyo-ku \\ Tokyo, 113 Japan \\ 金田研司 \\ 113 東京都文京区湯島 1-5-45 \\ 東京医科歯科大学医学部 \\ 第一解剖学教室
}

